\title{
Luxembourg's EU Council Presidency: Adapting Routines to New Circumstances
}

\author{
ANNA-LENA HÖGENAUER \\ University of Luxembourg
}

\section{Introduction}

Luxembourg took over the rotating presidency of the Council of the European Union on 1 July 2015 in a climate of internal and external crisis. The budgetary situation in Greece had worsened to the point where Greece's ability to remain in the eurozone (and the EU) was at stake. At the same time, a bank-run forced Greece's banks to temporarily close. Moreover, the refugee crisis reached a climax in 2015 and tensions between EU Member States about the handling of the situation and the distribution of refugees made a common approach difficult even in the face of humanitarian disaster. Furthermore, the Ukraine crisis simmered on. In addition, a terrorist attack in Paris brought internal security issues to the fore. Finally, following British Prime Minister David Cameron's promise of a referendum on whether Britain should remain in the European Union, the EU had to start a phase of renegotiation of certain policies and processes to allow Cameron to avoid Brexit.

The organization of this EU presidency fell to one of the smallest - but most experienced - Member States of the European Union. It was Luxembourg's 12th rotating presidency, which meant that many officials and some ministers had experienced at least one if not more previous presidencies. In addition, the institutional context of this presidency had also changed quite dramatically since the 11th Luxembourgish presidency in 2005 thanks to the Lisbon Treaty and the creation of the trio presidencies.

If one adopts Vandecasteele and Bossuyt's (2014) criteria for the performance of presidencies, the prospects for Luxembourg were mixed. In their review of the literature on the presidencies of the Council of the European Union, Vandecasteele and Bossuyt (2014, p. 241) identify conditions for presidency performance that fall into three categories: external context, national conditions and issue-specific characteristics. A favourable environment is seen as facilitating success, but external crises can also offer opportunities for leadership. By contrast Kietz (2007) underlines the extent to which external crises and highly sensitive dossiers challenge the ability of presidencies to reach compromise. In terms of national conditions, three appear key: good preparation, Brussels-based presidencies where the Permanent Representation has some leeway in the negotiations and a good reputation (which includes expertise and experience). Being a small state like Luxembourg can be advantageous, if it goes hand-in-hand with better communication within the ministries and a willingness to act as an honest broker, rather than defender of national interests (Vandecasteele and Bossuyt, 2004, pp. 241-242). But, as evidenced by Warntjen's (2007) analysis of the impact of presidencies on environmental 
policy-making, neither small nor large states can be said to have a systematic advantage. Quaglia and Moxon-Browne (2006) also emphasize the importance of 'intangible' factors like expertise, credibility and a pro-European attitude of the government holding the presidency based on their comparison of the Irish and Italian presidencies of 2003 and 2004.

The effect of issue-specific characteristics is more disputed, but it seems that qualified majority voting (QMV) makes it easier for the presidency to succeed in reaching an agreement and to shape that agreement (Tallberg, 2004; Warntjen, 2007). Also, diverse interests among actors may make it easier for the presidency to shape a compromise that reflects (some of) its own interests, but only if the disagreements are not too strong. Intense disagreements lower the chances of success (Vandecasteele and Bossuyt, 2014, p. 243).

In the light of these arguments, this contribution analyses how the difficult external context of the Luxembourgish presidency affected it in the context of the Lisbon Treaty, and to what extent the presidency could create the conditions for success. For this purpose, it will first review the context, resources and style of the presidency, before reviewing its priorities and achievements. ${ }^{1}$

\section{Managing the Presidency in a Changed Context}

\section{The Lisbon Treaty}

The Lisbon Treaty of 2009 introduced three important changes from the point of view of the rotating presidency. It created a new permanent president of the European Council, the High Representative - supported by the European External Action Service - became the chair of the Foreign Affairs Council and the Trio Presidency was modified. The first two changes in some way facilitated the work of the rotating presidency, as it reduced its workload and thus the resource requirements of presidencies. ${ }^{2}$

Luxembourg adapted quite well to the changed circumstances. It accepted that the big priorities are now set by the European Council and the Commission and that the Council of the European Union has become the legislative arm of the European Council. There was no competition between the permanent President of the European Council, Donald Tusk, and the Luxembourgish presidency of the Council of the European Union. ${ }^{3}$ In the same way, Luxembourg accepted that the presidency had lost influence over the EU's foreign policy. Instead of trying to develop priorities in this area - as some of the preceding presidencies had done - it mainly focused on supporting the High Representative. ${ }^{4}$

The emergence of key European posts reduced the pressure on the presidency in some areas. European Council President, Donald Tusk, for example, played a particularly important role in the negotiations with the United Kingdom on the reform of the EU as these negotiations fell clearly under the competence of the Heads of State or Government. Tusk insisted that David Cameron present his demands in written form and Cameron duly obliged (Cameron, 2015). In the same vein, the Greek crisis affected the presidency less than one might expect. Most of the emergency meetings were organized at the Eurogroup

\footnotetext{
${ }^{1}$ In addition to an analysis of relevant documents and news coverage, this contribution is based on interviews with an official of the Council of the European Union and seven officials from different Luxembourgish ministries and the Permanent Representation of Luxembourg.

${ }^{2}$ Interview with a member of the Luxembourgish Permanent Representation in Brussels, 24 February 2016.

${ }^{3}$ Interview with a Council official for Transport, Telecommunications, Energy, Brussels, 15 February 2016.

${ }^{4}$ Interview with an official of the Ministère des Affaires étrangères, Luxembourg, 25 February 2016.
} 
level and were thus chaired by the Eurogroup President, Jeroen Dijsselbloem. Some meetings took place at the level of Heads of State or Government and were thus chaired by Donald Tusk and only a few took place in the form of the Ecofin Council under Luxembourgish leadership. The presidency was mostly affected by certain issues spilling over into other dossiers (for example, budget negotiations) and by the general increase in workload for European finance ministries. ${ }^{5}$

However, other crises affected the presidency. Both the refugee crisis and debates about security in the aftermath of the terrorist attacks in Paris required the organization of a number of informal or extraordinary councils by the presidency.

In comparison, the modification of the Trio of rotating presidencies had little effect on the actual functioning of the rotating presidencies. Whereas formerly each presidency was supposed to cooperate with the preceding and the following presidency, the Trio now consists of a team of three countries that are supposed to coordinate their three presidencies over an 18-month period. In reality, interviewees felt that the Trio had little impact on the Luxembourgish presidency (and presidencies in general) (see also Warntjen, 2013). While officials appreciated the importance of drawing up a collective strategy, the strategy of the Trio was regarded as the least important influence on the priorities of the Luxembourgish presidency. ${ }^{6}$ Changes in the composition of the European Commission and the European Parliament meant that political preferences had shifted and the Trio strategy was no longer up-to-date.

In practice, the Luxembourgish presidency - which was the last in the Trio with Italy and Latvia ${ }^{7}$ - mainly cooperated with the preceding and following presidencies. In fact, cooperation with both Latvia and the Netherlands was very good. In the negotiations on the Juncker Plan, for example, Latvia allowed the Luxembourgish team to attend all trialogues with the European Parliament and the Commission as it was clear that this would spill over to the Luxembourgish presidency. ${ }^{8}$ On the railway package, the Luxembourgers and the Dutch worked together almost like a double presidency, as it was clear that the negotiations would continue during the Dutch presidency. ${ }^{9}$ The smooth transition between the Luxembourg and Dutch trios was helped by extensive experience of cooperation, for example, as part of the Benelux Union.

\section{Resources}

The Luxembourgish Presidency was relatively well-resourced in the context of the eurozone crisis. The budget for the Presidency in 2015 was $€ 71$ million (Ministère des Affaires étrangères, 2015). From a Luxembourgish perspective, these allocations were not overly generous. The guideline had been to keep the budget within the same margins as the budget of the presidency of 2005 plus inflation. ${ }^{10}$ Even though Luxembourg weathered the eurozone crisis comparatively well and could largely avoid painful budgetary cuts, approaches to public spending had become more cautious. On the other hand, the workload had become lighter now that the Foreign Affairs Council and the European

\footnotetext{
${ }^{5}$ Interview with two officials of the Ministère des finances, Luxembourg, 31 March 2016.

${ }^{6}$ Interview with an official of the Ministère des Affaires étrangères, Luxembourg, 25 February 2016.

${ }^{7}$ On the Italian presidency see Carbone (2015); on the Latvian presidency see Auers and Rostoks in this volume.

${ }^{8}$ Interview with two officials of the Ministère des finances, Luxembourg, 31 March 2016.

${ }^{9}$ Interview with a Council official for Transport, Telecommunications, Energy, Brussels, 15 February 2016.

${ }^{10}$ Interview with two officials, Ministère des Affaires étrangères, Luxembourg, 21 March 2016.
} 
Council are no longer chaired by the rotating presidency. ${ }^{11}$ On the whole the budget was relatively generous compared to that of other countries for which data are available: Lithuania's budget was around $€ 62$ million in 2013, Ireland's around $€ 45$ million in 2013 (half of what was spent during its presidency in 2004) and Spain's around $€ 55$ million in 2010 (Heywood, 2011; Laffan, 2014; Vilpišauskas, 2014). Only Poland adopted a generous budget of around $€ 100$ million (Pomorska and Vanhoonacker, 2012).

\section{Style}

As in the past, the Luxembourgish Presidency was organized as a Brussels-based presidency. The Permanent Representation in Brussels had enough leeway to run the negotiations relatively independently, as it was felt that this approach facilitates fast and effective negotiations. In addition, the heads of the permanent representation and of COREPER I and II and many Luxembourgish officials benefitted from the experience of previous presidencies. The Permanent Representation was helped by a generous allocation of temporary support staff and delegated civil servants (189 temporary support staff were hired in total), and the staff working on migration was further increased during the presidency when it became clear that the dossier would be more prominent than expected. ${ }^{12}$

The presidency was seen to be European and consensual in its approach. Luxembourg had no big national agenda and was praised for allowing the 'natural compromise' to emerge (for example, in the case of the fourth railway package). ${ }^{13}$ In this context, it is also interesting to note that the presidency did not regard the fact that Commission President Jean-Claude Juncker had been Prime Minister of Luxembourg from 1995-2013 as particularly important. The consensus among interviewees is that Juncker acted in line with the premise that Commissioners are not supposed to feel attached to a particular Member State and that his long experience as Luxembourgish Prime Minister only mattered in so far as it facilitated communication with the presidency.

In general, the presidency was perceived to be pragmatic and focused on compromisebuilding in line with the national culture of compromise (see also Hearl, 2006). In part this is also due to the fact that smaller states tend to be more aware of their relative weight in the Council, although there is a marked difference between the Belgian or Luxembourgish approach and the Latvian approach, which saw the presidency as an opportunity for a small state to have influence. ${ }^{14}$ Part of this pragmatism was also the adoption of a concise list or priorities (see below) that reflected the shift of competences to the High Representative and the Permanent President of the European Council. It was felt that Luxembourg could afford to be pragmatic, given its good reputation and long and positive track-records with presidencies. ${ }^{15}$

Finally, the presidency benefitted from the multilingualism of Luxembourgish officials, who generally speak French, German and English. In addition, they rotate less often than officials in other Member States and thus benefit from longer-term expertise in their area. The smaller size of the administration means that people know each other

\footnotetext{
${ }^{11}$ Interview with two officials, Ministère des Affaires étrangères, Luxembourg, 21 March 2016.

12 Interview with a member of the Luxembourgish Permanent Representation in Brussels, 24 February 2016. Interview with an official of the Ministère des Affaires étrangères, Luxembourg, 25 February 2016.

13 Interview with a Council official for Transport, Telecommunications, Energy, Brussels, 15 February 2016.

${ }^{14}$ Interview with a Council official for Transport, Telecommunications, Energy, Brussels, 15 February 2016.

${ }^{15}$ Interview with an official of the Ministère des Affaires étrangères, Luxembourg, 25 February 2016.
} 
better and that trust is easier to establish (Hearl, 2006). Moreover, they have also a more horizontal view of policies as the small size of the administration means that people often work on several dossiers. ${ }^{16}$

\section{Priorities and Progress}

The preparations of the presidency in terms of content were delayed until late 2014 by the election of the European Parliament in 2014 and the subsequent nomination of a new European Commission. These political developments meant that the views of several important European institutions were changing, which influenced in turn what goals the Council Presidency could realistically achieve. ${ }^{17}$ In the end, the priorities took into account the stated priorities of the European Council (2014), the policy orientations of the Juncker Commission, the annual work programme of the Commission and - to a lesser extent - the work programme of the Trio (Luxembourgish Presidency, 2015a).

In line with the pragmatic style of the presidency, the priorities were summarized in a relatively short document of 33 pages, the shortest in the last six presidencies. The aim was to have a realistic and feasible programme. A common thread was concerns with a more competitive but also a more social Europe as well as with a shift to a more modern, green economy (Luxembourgish Presidency, 2015a).

\section{Stimulating Investment to Boost Growth and Employment}

In the context of the eurozone crisis, high unemployment and low growth was one of the key priorities of the presidency. An important element was the support for the Investment Plan for Europe by reducing barriers to investment and improving regulation. ${ }^{18}$ In addition, the presidency achieved progress in several dossiers related to capital markets union, for example, by reaching political agreement on a proposal to relaunch the simple, transparent and standardized securitisation in just nine weeks (Renman and Russack, 2016). ${ }^{19}$

Another important achievement was the introduction of a new working method in the Competitiveness Council: the 'competitiveness check-up'. Under this new procedure, the beginning of Competitiveness Council meetings will be dedicated to an assessment of competitiveness based on certain indicators. In addition, the Competitiveness Council should broaden its debates by also considering issues that fall into the domain of other formations (for example, social affairs, environment or transport), but that could have an impact on competitiveness (Competitiveness Council, 2015; Luxembourgish Presidency, 2015b).

Finally, a major success of the Luxembourgish presidency were the negotiations of the EU's annual budget where the presidency managed to reach a unanimous agreement within the timeframe. This was the first time since the start of the financial crisis in 2008 that the Council agreed unanimously on the budget. ${ }^{20}$

\footnotetext{
${ }^{16}$ Interview with an official of the Ministère des Affaires étrangères, Luxembourg, 25 February 2016.

${ }^{17}$ Interview with an official of the Ministère des Affaires étrangères, Luxembourg, 25 February 2016.

${ }^{18}$ Interview with two officials of the Ministère des finances, Luxembourg, 31 March 2016.

${ }^{19}$ See Quaglia et al's contribution to this volume.

${ }^{20}$ See Quaglia et al's contribution to this volume.
} 


\section{Deepening the European Union's Social Dimension}

The presidency aimed to encourage progress towards a Europe with a 'Triple A social rating' by boosting social investment. In this context, one non-legislative goal was to encourage (or even force) debate on the social dimension of the eurozone. This aim was difficult and even controversial, as the eurozone crisis had brought different approaches to the social dimension to the fore. In addition to discussions in the employment, social policy, health and consumer affairs (EPSCO) council, the presidency held a tripartite social summit in October 2015. It also organized the first ever informal Council of the Ministers for Employment and Social Affairs of the eurozone countries to discuss the social dimension of EMU. In this case, the government went against its culture of consensus and deliberately organized the meeting knowing that it would be contentious. ${ }^{21}$ While several council decisions and conclusions were adopted during the presidency, for example the decision on guidelines for employment policies in the Member States, it is questionable whether EU policies became noticeably more social in substance.

\section{Managing Migration, Combining Freedom, Security and Justice}

Luxembourg was firmly committed to a European solution to the migration crisis and to an approach that respects established European values and the rule of law. The presidency managed to broker a number of difficult agreements, such as the conclusions of the Justice and Home Affairs (JHA) Council on the relocation of 160,000 people and the resettlement of 22,504 people in July and September 2015. In addition, the Council agreed in October to earmark almost half a billion euro of additional funding for the management of the migration crisis in the EU budget, allowing for the creation of 120 new positions in the relevant EU agencies. The Council also adopted conclusions on a new returns and readmission policy and prepared the ground for the EU-Turkey agreement on refugees during a summit in November. At the same time, the migration crisis actually illustrated both views on the impact of external crises on presidencies (Vandecasteele and Bossuyt, 2014). On the one hand, it offered the presidency the opportunity to play a stronger agenda-shaping role than in 'ordinary' legislative business. At the same time, the intensity of disagreement among Member States made it extremely difficult to reach decisions (Luxembourgish Presidency, 2015c). Despite the extensive efforts of Foreign Minister Jean Asselborn, it was not possible to reach consensus. The decision of the Council on quotas was thus the first decision in this policy area to be taken by qualified majority vote rather than unanimity since the Treaty of Lisbon. ${ }^{22}$ It was a radical decision, but the presidency felt that consensus was out of reach. The fact that several Member States that 'lost' the vote brought a case before the European Court of Justice (ECJ) further illustrates the intensity of the debate. ${ }^{23}$ The corresponding foot-dragging at the implementation stage reduced the effectiveness of the policy.

In the aftermath of the terrorist attacks in Paris concerns about security increased. The presidency held an extraordinary JHA Council meeting to discuss the coordination of responses to terrorism and improved cooperation between Member States. ${ }^{24}$ The

\footnotetext{
${ }^{21}$ Interview with an official of the Ministère des Affaires étrangères, Luxembourg, 25 February 2016.

22 BBC News, 22 September 2015, http://www.bbc.com/news/world-europe-34329825.

${ }^{23}$ Interview with an official of the Ministère des Affaires étrangères, Luxembourg, 19 April 2016.

${ }^{24}$ On developments in the field of Justice and Home Affairs see Monar's contribution to this volume.
} 
presidency managed to broker a compromise between Member States and between the Council and the Parliament on the European passenger name record, a dossier that had been blocked for years with disagreements on data protection. ${ }^{25}$ Similarly, the presidency reached an informal agreement with the European Parliament in trialogue on the Data Protection Package (Renman and Russack, 2016).

\section{Revitalising the Single Market by Focusing on its Digital Dimension}

An important success in this dimension was the advancing of the two most sensitive elements in the fourth railway package. ${ }^{26}$ The aim of the Commission was to liberalize passenger transport service and to strengthen railway infrastructure governance by separating railway and infrastructure companies. The final compromise in the Council was a more functional separation rather than a clear division of the two types of companies. In addition, countries can still directly allocate the contract to a company subject to certain conditions. This compromise is seen to be the 'logical compromise', but also a fragile compromise as positions on liberalization diverge. ${ }^{27}$ Similarly, in the case of the Council Conclusions on Energy Governance, thorough preparation allowed the presidency to broker an agreement on a completely new file in a very short time. It was an important dossier for Luxembourg as the administrative burden of reporting on different aspects of energy at different intervals is particularly difficult to manage for small Member States (Council, 2015). ${ }^{28}$

The successful climate talks at the $21^{\text {st }}$ Conference of Parties at the United Nations Framework Convention on Climate Change (COP21) in Paris were another important milestone although France and the Commission also played a major part in their negotiation. In this case, the Luxembourgish presidency played a role in the coordination of a common position within the European Union whereas France and the Commission then took the lead in the actual COP21 negotiations.

\section{Placing European Competitiveness in a Global and Transparent Framework}

This important pillar included both discussion about the future direction of EMU, and various tax-related policies. As the latter concerned mainly the prevention of tax evasion within Europe and in a global context, this was a salient dossier for Luxembourg, which had come to be seen as a tax haven for multi-national corporations following the Luxleaks affair. $^{29}$

The presidency nevertheless made important progress. It rapidly reached a political agreement on the directive on cross-border tax ruling. In addition, the presidency finalized work on the OECD Base Erosion and Profit Shifting Initiative (Luxembourgish Presidency, 2016).

\footnotetext{
${ }^{25}$ Interview with an official of the Ministère des Affaires étrangères, Luxembourg, 19 April 2016.

${ }^{26} \mathrm{http}: / /$ ec.europa.eu/transport/modes/rail/packages/2013_en.htm

27 Interview with a Council official for Transport, Telecommunications, Energy, Brussels, 15 February 2016.

${ }^{28}$ Interview with a member of the Luxembourgish Permanent Representation in Brussels, 24 February 2016. Interview with a Council official for Transport, Telecommunications, Energy, Brussels, 15 February 2016.

${ }^{29}$ Deutschlandfunk, 24 July 2015, http://www.deutschlandfunk.de/luxemburg-vor-dem-eu-ratsvorsitz-griechenland-undandere.724.de.html?dram:article_id=324007.
} 
The presidency was also marked by progress on trade agreements. In the case of the Transatlantic Trade and Investment Partnership with the US, the Luxembourgish presidency promoted demands by civil society to create reading rooms to give national parliamentarians access to the relevant documents.

\section{Promoting Sustainable Development}

This pillar, which overlaps with the fourth pillar, was salient as it gained global attention in two major conferences, the Special Summit on Sustainable Development in New York in September 2015 and COP21 in Paris in December 2015 (see above).

Internally, the reform of the emissions trading scheme (ETS) was a key issue. The market stability reserve was adopted in September as a first step towards the reform of the ETS. In addition, the first policy debate on the reform of the ETS was held during the environment council in October.

The presidency also tackled various questions of sustainability in the context of agricultural and fisheries policy. It was able to broker an agreement on the 2016 fishing quotas for certain fish stocks in December with a view to integrating sustainability into this policy area.

\section{Strengthening the European Union's Presence on the Global Stage}

This was the least ambitious pillar of the presidency's programme as it was deemed to fall largely under the remit of the High Representative of the European Union and the European External Action Service. However, the presidency organized the $12^{\text {th }}$ AsiaEuropean foreign ministers' meeting, which brought together 53 delegations. It also encouraged an active enlargement policy and was pleased that a particularly high number of chapters were opened during accession negotiations. ${ }^{30}$ New chapters were opened for negotiation with Turkey and Montenegro and accession negotiations with Serbia began.

\section{Perceptions of the Presidency}

On the whole, despite the crises that affected the European Union, the Luxembourgish presidency itself was generally seen positively by politicians and the media. ${ }^{31}$ The plenary debate in the European Parliament on the 'bilan de la présidence' was overwhelmingly positive. Criticism came mostly from the extreme right on migration, from the left on the need for even more social measures and there was still some criticism on Luxembourg's past policy on corporate taxation (European Parliament, 2016).

The presidency did well on its legislative programme, concluding 34 legislative files under the ordinary legislative procedure (Luxembourgish Presidency, 2016). This number is low compared to other presidencies, but it is the result of a deliberate reduction in new legislation on the part of the European Commission under Barroso and Juncker. ${ }^{32}$ The Luxembourgish presidency also managed to negotiate a new interinstitutional agreement to facilitate better law-making in the European Union (Renman and Russack, 2016).

\footnotetext{
${ }^{30}$ Interview with an official of the Ministère des Affaires étrangères, Luxembourg, 19 April 2016.

${ }^{31}$ France Inter, 1 January 2016; Le Quotidien, 19 December 2015.

${ }^{32}$ Interview with a Council official for Transport, Telecommunications, Energy, Brussels, 15 February 2016.
} 


\section{Conclusion}

Overall, despite the context of crisis, the presidency successfully concluded or advanced a range of important dossiers - at times quite rapidly. Part of the explanation is that the presidency had adopted a realistic programme to begin with. In addition, the presidency managed to create many of the conditions for success outlined by Vandecasteele and Bossuyt (2014). As far as national conditions are concerned, it benefited from a high level of experience and a culture of consensus, but also from a climate of trust between different Luxembourgish actors. This allowed it to become a truly Brussels-based presidency that focused on being an honest broker. Also, while it could only fix its priorities comparatively late, it was well prepared on its priorities. At the same time, unexpected shifts in the agenda or the nature of policy problems, such as the sudden prominence of the eastern route for refugees, clearly made it difficult for all actors to forge compromises.

In terms of crises, the presidency was to some extent shielded by the provisions of the Lisbon Treaty. Both the migration crisis and the terrorist attacks in Paris, however, left their mark on the presidency. The early decisions in the migration crisis, in particular, were an achievement, but also controversial. This example also illustrates the importance of being able to take decisions with qualified majority voting. At the same time, it is now obvious that Member States are reluctant to accept being outvoted in a policy area that touches what is perceived to be fundamental national interests.

\section{References}

Cameron, D. (2015) 'A New Settlement for the United Kingdom in a Reformed European Union', Letter to Donald Tusk on 10 November 2015. Available online at: http://www.consilium.europa.eu/en/policies/uk/2016-uk-settlement-process-timeline/.

Carbone, M. (2015) 'Beyond the Telemachus Complex: Courses, Discourses and the 2014 Italian Presidency of the Council of the European Union'. JCMS, Vol. 53, No. s1, pp. 83-92.

Competitiveness Council (2015) Outcome of the Council Meeting, Presse 12578/15, 1 October.

European Council (2014) 'Conclusions 26/27 June: Strategic Agenda for the Union in Times of Change'. Available online at: http://www.consilium.europa.eu/en/european-council/role-setting-eu-political-agenda/.

European Parliament (2016) 'Bilan de la présidence luxembourgeoise (débat)', plenary debate, 19 January. Available online at : http://www.europarl.europa.eu/sides/getDoc.do?pubRef=-//EP// TEXT+CRE+20160119+ITEM-003+DOC+XML+V0//FR\&language $=F R$.

Hearl, D. (2006) 'The Luxembourg Presidency: Size Isn't Everything'. JCMS, Vol. 44, No. s1, pp. $51-5$.

Heywood, P. (2011) ‘Spain’s EU Presidency: Ambitions beyond Capacity?’ JCMS, Vol. 49, No. s1, pp. 77-89.

Kietz, D. (2007) 'Funktionen, Handlungsbedingungen und Stellschrauben der Präsidentschaft im System des EU-Ministerrats'. In Kietz, D. and Perthes, V. (eds.), Handlungsspielräume einer EU-Ratspräsidentschaft. Eine Funktionsanalyse des deutschen Vorsitzes im ersten Halbjahr 2007 (Berlin: SWP Studie).

Laffan, B. (2014) 'In the Shadow of Austerity: Ireland's Seventh Presidency of the European Union'. JCMS, Vol. 52, No. s1, pp. 90-8. 
Luxembourgish Presidency (2015a) 'A Union for the Citizens: Priorities of the Luxembourg Presidency', (Luxembourg: Information and Press Service of the Luxembourg Government). Available online at: http://www.eu2015lu.eu/en/la-presidence/a-propos-presidence/programme-et-priorites/.

Luxembourgish Presidency (2015b), 'Informal meeting in Luxembourg of Ministers for Competitiveness within the EU', 20-21 July. Available online at: http://www.eu2015lu.eu/en/ actualites/communiques/2015/07/info-comp-annonce/.

Luxembourgish Presidency (2015c) 'Première réunion informelle des ministres de l'Emploi de la zone euro - Le renforcement de la dimension sociale dans l'UEM au centre des discussions', 5 October. Available online at: http://www.eu2015lu.eu/fr/actualites/articles-actualite/2015/10/ 05-info-epsco-eurozone/index.html.

Luxembourgish Presidency (2016) 'Report on the Achievements of the Luxembourg Presidency' (Luxembourg: Information and Press Service of the Luxembourg Government).

Ministère des Affaires étrangères (2015) 'Réponse de Monsieur le Ministre des Affaires étrangères et européennes à la question parlementaire N'SyO déposée par les honorables Députés Messieurs Justin Turpel et Serge Urbany (Groupe parlementaire Déi Lénk)', Chambre des Députés, 27 February.

Pomorska, K. and Vanhoonacker, S. (2012) 'Poland in the Driving Seat: A Mature Presidency in Turbulent Times'. JCMS, Vol. 50, No. s1, pp. 76-84.

Quaglia, L. and Moxon-Browne, E. (2006) 'What Makes a Good EU Presidency? Italy and Ireland Compared'. JCMS, Vol. 44, No. 2, pp. 349-68.

Renman, V. and Russack, S. (2016) 'Balancing Priorities and Emergency Measures: Luxembourg's Council Presidency', CEPS, EPIN Commentary No 30. 15 January.

Tallberg, J. (2004) 'The Power of the Presidency: Brokerage, Efficiency and Distribution in EU Negotiations'. JCMS, Vol. 42, No. 5, pp. 999-1022.

Vandecasteele, B. and Bossuyt, F. (2014) 'Assessing EU Council Presidencies: (Conditions for) Success and Influence'. Comparative European Politics, Vol. 12, No. 2, pp. 233-47.

Vilpišauskas, R. (2014) 'Lithuania's EU Council Presidency: Negotiating Finances, Dealing with Geopolitics'. JCMS, Vol. 52, No. s1, pp. 99-108.

Warntjen, A. (2007) 'Steering the Union. The Impact of the EU Presidency on Legislative Activity in the Council.' JCMS, Vol. 45, No. 5, pp. 1135-1157.

Warntjen, A. (2013) 'The Elusive Goal of Continuity? Legislative Decision-Making and the Council Presidency before and after Lisbon'. West European Politics, Vol. 36, No. 6, pp. 1239-55. 